\title{
Spatiotemporal variability of inorganic nitrogen stocks and uptake fluxes in the Scotia-Weddell Confluence area during November and December 1988
}

\section{Leo Goeyens ${ }^{1}$, Fred Sörensson ${ }^{2}$, Paul Tréguer $^{3}$, Jean Morvan ${ }^{4}$, Michel Panouse $^{5}$, Frank Dehairs ${ }^{1}$}

\author{
${ }^{1}$ Vrije Universiteit Brussel, Laboratorium voor Analytische Chemie, Pleinlaan 2, B-1050 Brussel, Belgium \\ ${ }^{2}$ Göteborgs Universitet, Avdelningen för Allmän och Marin Mikrobiologi, Carl Skottsbergs Gata 22, S-41319 Göteborg, \\ Sweden \\ ${ }^{3}$ Université de Bretagne Occidentale, Institut d'Etudes Marines, Avenue Le Gorgeu 6, F-29287 Brest Cedex, France \\ ${ }^{4}$ Université de Rennes, Ecole Nationale Supérieure de Chimie de Rennes, Avenue du Général Leclerc, \\ F-35700 Rennes-Beaulieu, France \\ ${ }^{5}$ Observatoire Océanologique de Banyuls, F-66650 Banyuls-sur-Mer, France
}

\begin{abstract}
Distributions of nitrate and ammonium and corresponding uptake fluxes were investigated in the Scotia-Weddell Confluence area during EPOS LEG 2 (November and December 1988) on board RV 'Polarstern' In this area a central low-salinity and low-nitrate compartment extends southward from the Scotia Front over 1 to $1.5^{\circ}$ latitude. High ammonium concentrations and marked nitrate depletions indicate an enhanced biological activity in this part of the ocean. By means of the uptake rates, obtained from ${ }^{15} \mathrm{~N}$ incubations, and of nitrate depletion data it is proved that this marginal ice zone ecosystem shifts from predominantly new production based (highest $\mathrm{f}$-ratio 0.83 ) to regenerated production based (lowest f-ratio 0.30) after some $3 \mathrm{wk}$. This transition corresponds with the change from a higher diatom presence to a higher flagellate presence in the phytoplankton community. Moreover, it is in agreement with the described sudden termination of export fluxes in the Weddell Sea.
\end{abstract}

\section{INTRODUCTION}

Considering the abundance of macronutrients - inorganic nitrogen as well as other elements - the Antarctic Ocean should be classified amongst the highly productive areas of the world ocean. However, the region south of the Polar Front exhibits the unique property of surface nutrient concentrations remaining very high during the growth season. Throughout the year surface nitrate concentrations in the different sectors of this ocean exhibit a slight positive gradient, varying from about $20 \mu \mathrm{mol} \mathrm{N} \mathrm{^{-1 }}$ at the Antarctic Convergence to concentrations between 25 and $30 \mu \mathrm{mol} \mathrm{N} \mathrm{l^{-1 }}$ at the Antarctic Divergence (Gordon \& Molinelli 1982, Sharp 1983, Jones et al. 1990)

The elucidation of the surface nitrogen patterns in the Southern Ocean requires the consideration of chemical and biological fluxes mainly during the growth season. Kamykowski \& Zentara (1985) point out that the water south of the Subtropical Convergence exhibits a potential for nitrate excess at silicate depletion, the greatest excess occurring at the Antarctic Convergence and declining towards the Antarctic continent. Moreover, this southward decrease in nitrate excess is continued by the occurrence of silicate excess in the Ross Sea (Nelson \& Smith 1986) and Weddell Sea. This nitrogen signature suggests the importance of nitrogen recycling for phytoplankton growth and its apparent decrease with increasing latitude. The importance of remineralization, occurring in the upper $100 \mathrm{~m}$ of the water column at different regions of the Southern Ocean, has been confirmed by several other authors (Biggs 1982, Le Jehan \& Tréguer 1983, 1985, Koike et al. 1986). The more detailed study on the spatial and temporal variability of nutrients in the Southern Ocean by Kamykowski \& Zentara (1989) indi- 
cates that the utilization of nitrate and ammonium by phytoplankton is nearly equal in the region extending from the coast of Antarctica to the Antarctic Divergence, whereas ammonium is likely to be the dominant nitrogen source between the Divergence and the Polar Front. In this latter zone the importance of ammonium is predominant around $60^{\circ} \mathrm{S}$, the latitude of the northernmost winter ice extension.

Different studies on nitrogen assimilation in the Southern Ocean have revealed that phytoplankton meets a large part of its nitrogenous needs by taking up ammonium despite high ambient concentrations of nitrate. Olson (1980) shows that, for a study carried out in the Scotia Sea during September and October, the f-ratio varies between 0.18 and 0.70 with an average value of 0.54 for all stations. In late summer, when ammonium concentrations in the same area have increased to values of 1 umol $\mathrm{N} \mathrm{I}^{-1}$ and more, phytoplankton obtains more than $60 \%$ of its nitrogen demand in the form of ammonium (Glibert et al. 1982). These results are complemented by later investigations in the same area and in the Weddell Sea. Rönner et al. (1983) and Koike et al. (1986) also indicate the predominant importance of ammonium as a nitrogen source for phytoplankton: average f-ratios for the data available in their papers are respectively 0.14 and 0.22 . In contrast to results from the open ocean, Smith \& Nelson (1990) report nitrate was the major source of inorganic nitrogen taken up by phytoplankton in the marginal ice zone of the Weddell Sea. Integrated f-ratios for the euphotic zone average respectively 0.52 for austral spring investigations (November 1983) and 0.71 for austral fall (March 1986). Their observations are consistent with previous findings for a phytoplankton bloom at the western Ross Sea ice edge (Nelson \& Smith 1986). Nevertheless, the relative preference indices for ammonium indicate that it is nearly always the preferred nitrogen form for phytoplankton growth in polar as well as in temperate regions (Smith \& Harrison 1991). Thus, antarctic phytoplankton does not display a different nitrogen preference, even when living in a vast nitrate reservoir.

Additionally, accumulating evidence suggests that the amount of regenerated production, the dominant size class and the dominant species within the phytoplankton community are linked. Several observations (Bröckel 1981, 1985, Probyn \& Painting 1985, Nelson \& Smith 1986) describe the preponderant importance of picoplanktonic and nanoplanktonic $(<20 \mu \mathrm{m})$ forms for primary production. Only Nelson \& Smith (1986) emphasize that, for an intensive diatom bloom at the receding ice edge, nitrate uptake prevails over ammonium uptake. This is in contrast with the other studies, where it is clearly described that the phytoplankton community consisted mainly of flagellates and/or dinoflagellates. This apparent contradiction can possibly be interpreted in terms of growth season maturity, since it becomes increasingly clear that the Antarctic pelagic system undergoes a seasonal succession from a diatom-dominated to a flagellate-dominated bloom (Holm-Hansen 1985, Koike et al. 1986).

During the EPOS LEG 2 cruise (Smetacek \& Veth 1989), primarily devoted to the study of the pelagic system, we undertook the quantification of inorganic nitrogen stocks and assimilatory fluxes at the first trophic level, and their variability in relation to biomass distribution and to seasonal phytoplankton development. The use of ${ }^{15} \mathrm{~N}$ to measure nitrogen uptake allowed us to distinguish between new and regenerated production and to estimate the impact on export production (Dugdale \& Goering 1967, Eppley \& Peterson 1979). Additionally, a more conservative approach, based on the mathematical treatment of surface nitrate depletion values (Le Corre \& Minas 1983, Jennings et al. 1984), was applied to determine total amounts of nitrate taken up by phytoplankton during the ongoing growth season.

\section{METHODS}

This study was carried out during the EPOS LEG 2 cruise with RV 'Polarstern' in the Scotia Weddell area (Fig. 1) from November 22, 1988 to January 9, 1989. The sector covered is delimited by 57 and $62^{\circ} \mathrm{S}$ and by 47 and $49^{\circ} \mathrm{W}$. Forty-five hydrographic stations were occupied on 4 consecutive north to south transects along $49^{\circ} \mathrm{W}$ and one parallel transect along $47^{\circ} \mathrm{W}$. The western transects are respectively denoted as W1 (Stns 143 to 153 , Nov 26 to Nov 30), W2 (Stns 154 to 159, Nov 30 to Dec 12), W3 (Stns 172 to 179 , Dec 20 to Dec 24) and W4 (Stns 182 to 194, Dec 27 to Dec 31). The eastern transect along $47^{\circ} \mathrm{W}$, denoted as $E$, consisted of Stns 160 to 169 (Dec 13 to Dec 17). Sampling for physical, chemical and biological parameters was done at every half degree of latitude with a standard CTD rosette sampler, equipped with 12 I Niskin bottles.

Nitrate plus nitrite was determined with a Technicon Autoanalyzer II, according to the method of Tréguer \& Le Corre (1975). Millipore Milli Q water was used as zero level; calibration was carried out against 4 potassium nitrate standards in the range 20 to $40 \mu \mathrm{mol} \mathrm{N}{ }^{-1}$. Ammonium concentrations were determined manually, as described by Koroleff (1969). Freshly prepared Millipore Milli $Q$ water served as the blank solution; standardization was carried out with 5 ammonium sulphate standards between 0 and $3 \mu \mathrm{mol} \mathrm{N} \mathrm{I}^{-1}$. These data, together with salinity, pressure, temperature, oxygen, chlorophyll and other nutrient values, are listed in EPOS LEG 2 (1989).

The incubations for the study of nitrogen uptake 


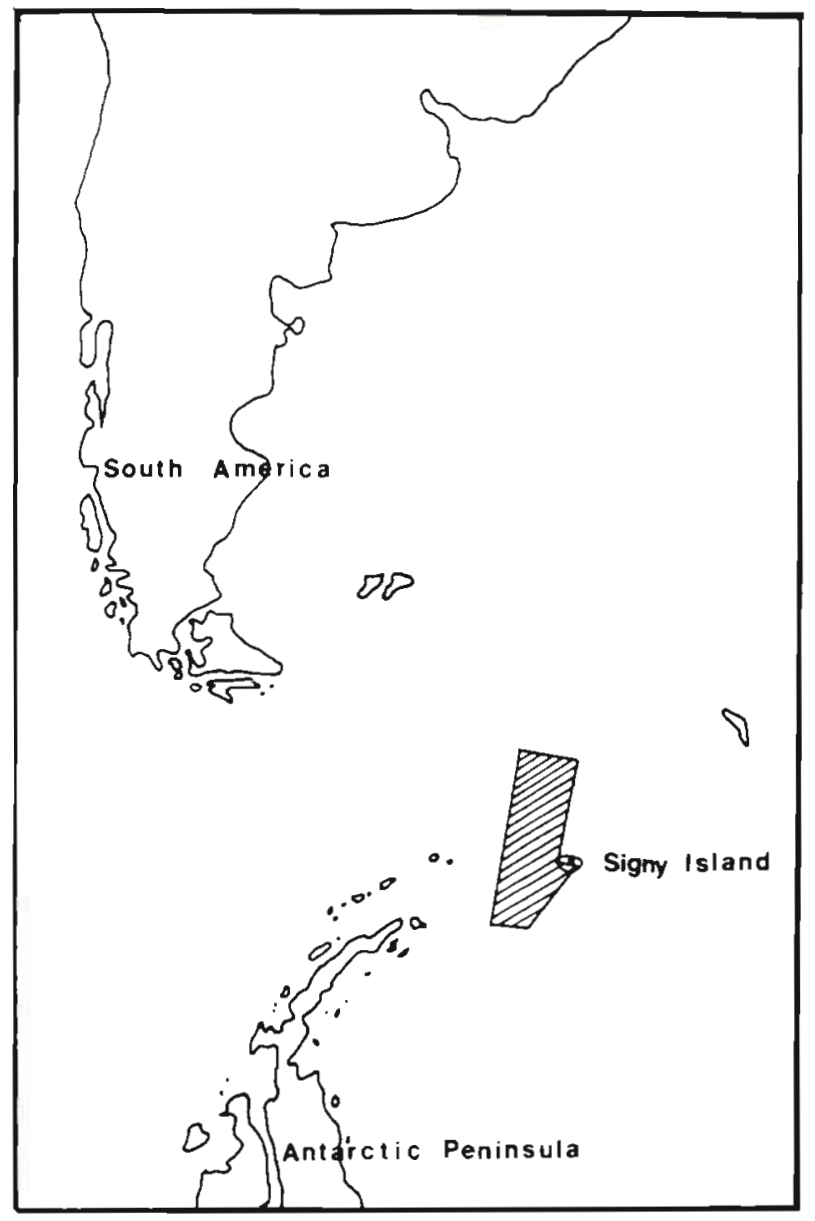

Fig. 1. Area studied during EPOS LEG 2

rates were started immediately after adding ${ }^{15} \mathrm{~N}$ labelled nitrate or ammonium (99\% atom $\left.{ }^{15} \mathrm{~N}\right)$ to the samples in 41 polycarbonate bottles. Spike additions increased the concentrations by about $10 \%$. All bottles were incubated for $24 \mathrm{~h}$ at $0{ }^{\circ} \mathrm{C}$, with a $16 \mathrm{~h}: 8 \mathrm{~h}$ light: dark cycle. Incident radiation was $100 \mu \mathrm{E} \mathrm{m}^{-2} \mathrm{~s}^{-1}$. The particulate material in the samples was collected onto Whatman GF/F glass fiber filters; particulate nitrogen was converted to $\mathrm{N}_{2}$ by a Dumas combustion method, according to Kristiansen \& Paasche (1982). The ${ }^{14} \mathrm{~N} /{ }^{15} \mathrm{~N}$ ratio was measured by emission spectrometry with a Statron NOI- $5{ }^{15} \mathrm{~N}$ Analyzer. The content of particulate carbon and nitrogen was determined using a Carlo Erba 1106 Elemental Analyzer.

For ${ }^{14} \mathrm{C}$ incubations the samples were taken at 6 depths, corresponding respectively to $100,25,10,3,1$ and $0.1 \%$ of surface irradiance. The water was collected with Niskin bottles, fitted with stainless steel clamps coated with teflon and mounted on a new steel hydrowire. Inside a laminar flux hood and within $30 \mathrm{~min}$ after collection, the samples were poured into $250 \mathrm{ml}$ clean polycarbonate flasks fitted with neutral density screens to in-situ light intensity. Then $25 \mu \mathrm{l}$ of ${ }^{14} \mathrm{C}$ solution $\left(\mathrm{NaH}^{14} \mathrm{CO}_{3}\right.$ solution, provided by CEA-F, stored in glass vials, specific activity $31 \mathrm{~Bq} \mathrm{ug}^{-1}$ ) was added to each sample. Incubations were carried out for $9 \mathrm{~h}$ in natural daylight inside a transparent plexiglass incubator, maintained at constant temperature $\left(1\right.$ to $1.5^{\circ} \mathrm{C}$ over that of surface water) by a continuous flow of surface sea water. After incubation the samples were gently vacuum-filtered onto $0.45 \mu \mathrm{m}$ Millipore filters $(25 \mathrm{~mm}$ diameter). The beta activity of the filters was counted using liquid scintillation counting aboard RV 'Polarstern'.

\section{RESULTS}

\section{Nitrogenous nutrients}

Vertical distributions of salinity and dissolved inorganic nitrogen for 4 north to south transects along $49^{\circ} \mathrm{W}$ and for 1 transect along $47^{\circ} \mathrm{W}$ show the existence of a central low-salinity lens, with significant decrease in surface nitrate and enhanced ammonium in the subsurface layer, extending between ca 59 and $61^{\circ} \mathrm{S}$. The potential temperature data show that its northern border fits well with the Scotia Front (Cederlöf et al. 1989).

The potential temperature contour plot for Transect W1 (Fig. 2) shows clearly that the Scotia Front is situated near $58^{\circ} \mathrm{S}$. South of this front surface nitrate concentrations decrease to $19.0 \mu \mathrm{mol} \mathrm{N}{ }^{-1}$ at $59^{\circ} \mathrm{S}$, and at the same spot salinities less than 33.75 practical salinity units (psu) were measured. This latitude was also characterized by substantial amounts of ammonium present in the subsurface layer, with a maximal con-

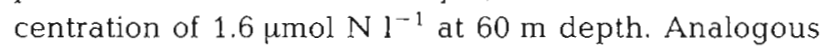
properties were found up to $60^{\circ} \mathrm{S}$. At the more southern stations (between 60 and $62^{\circ} \mathrm{S}$ ) surface nitrate amounted to more than $30.0 \mu \mathrm{mol} \mathrm{N} \mathrm{l^{-1 }}$ and maximal ammonium concentrations were as low as $0.2 \mu \mathrm{mol} \mathrm{N}$ $1^{-1}$. For the northern part of the study area (between 57 and $58^{\circ} \mathrm{S}$ ) an intermediate situation was found with nitrate concentrations of $24.4 \mu \mathrm{mol} \mathrm{N}{ }^{-1}$ and maximal ammonium concentrations of $0.6 \mu \mathrm{mol} \mathrm{N} \mathrm{l}^{-1}$. Transects W2 and W3 were very similar to the one described, but as they do not include a station at every half degree of latitude a graphical presentation is omitted. The last transect along $49^{\circ} \mathrm{W}$ (W4) again covered the complete distance from 57 to $62^{\circ} \mathrm{S}$ and here too the distinct central sector, typical for the Confluence Area (Fig. 3), can be seen. As the Scotia Front was more expanded than during the first transect, the position of the lowsalinity, low-nitrate lens shifted about $1^{\circ}$ southward. Its lowest measured nitrate concentration was $19.7 \mu \mathrm{mol} N$ $\mathrm{I}^{-1}$ at $59^{\circ} \mathrm{S}$ and the maximal ammonium concentration at the same latitude was $2.3 \mu \mathrm{mol} \mathrm{N} 1^{-1}$. These proper- 

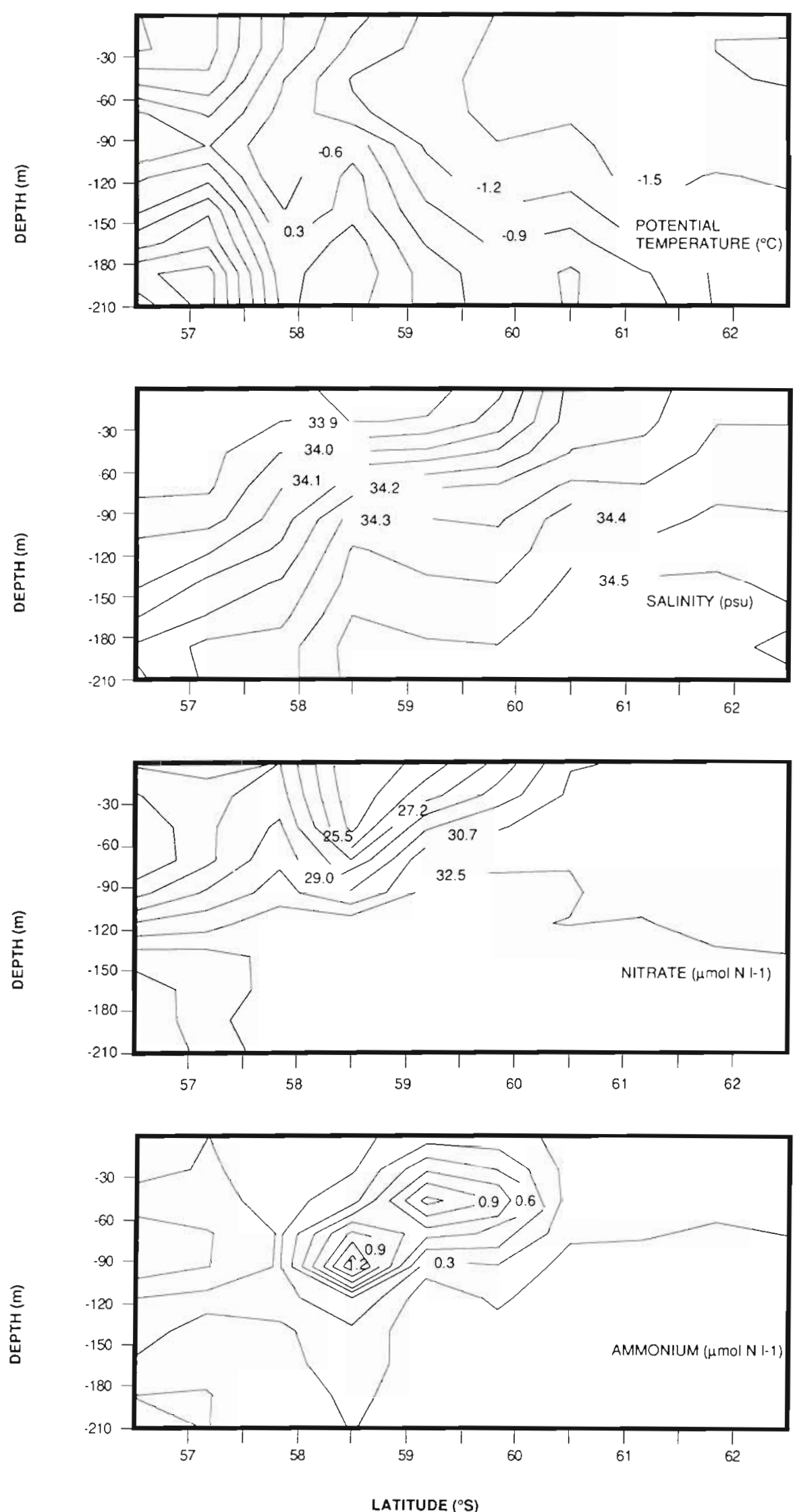

Fig. 2. Vertical distributions of potential temperature $\left({ }^{\circ} \mathrm{C}\right)$, salinity (psu), nitrate (umol $\mathrm{N}^{-1}$ ) and ammonium ( $\mu \mathrm{mol} \mathrm{N}^{-1}$ ) for the western transect $W 1$ 

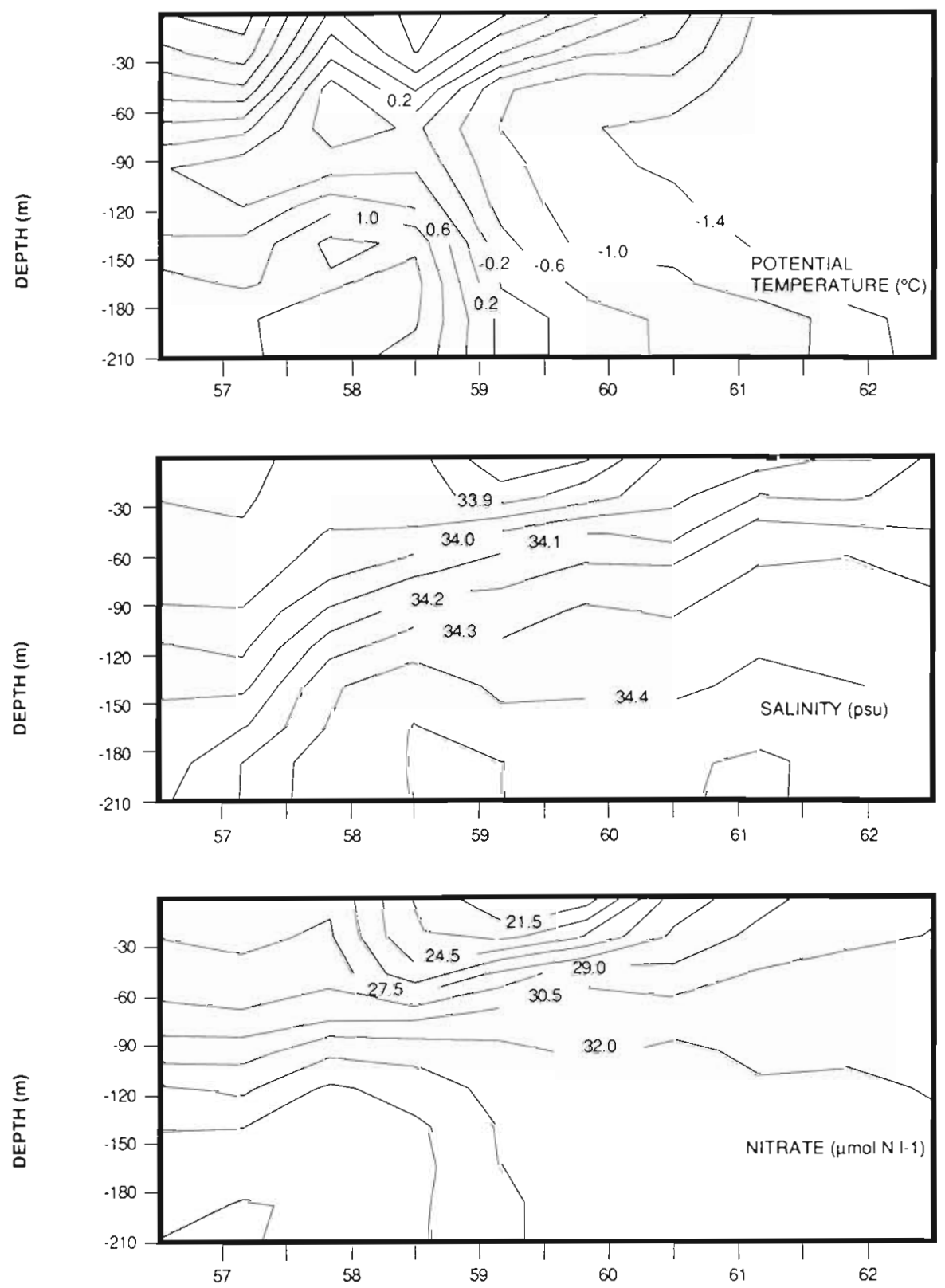

Fig. 3. Vertical distributions of potential temperature $\left({ }^{\circ} \mathrm{C}\right)$, salinity (psu), nitrate (umol $\mathrm{N}^{-1}$ ) and ammonium $\left(\mu \mathrm{mol} \mathrm{Nl}^{-1}\right)$ for the western transect W4

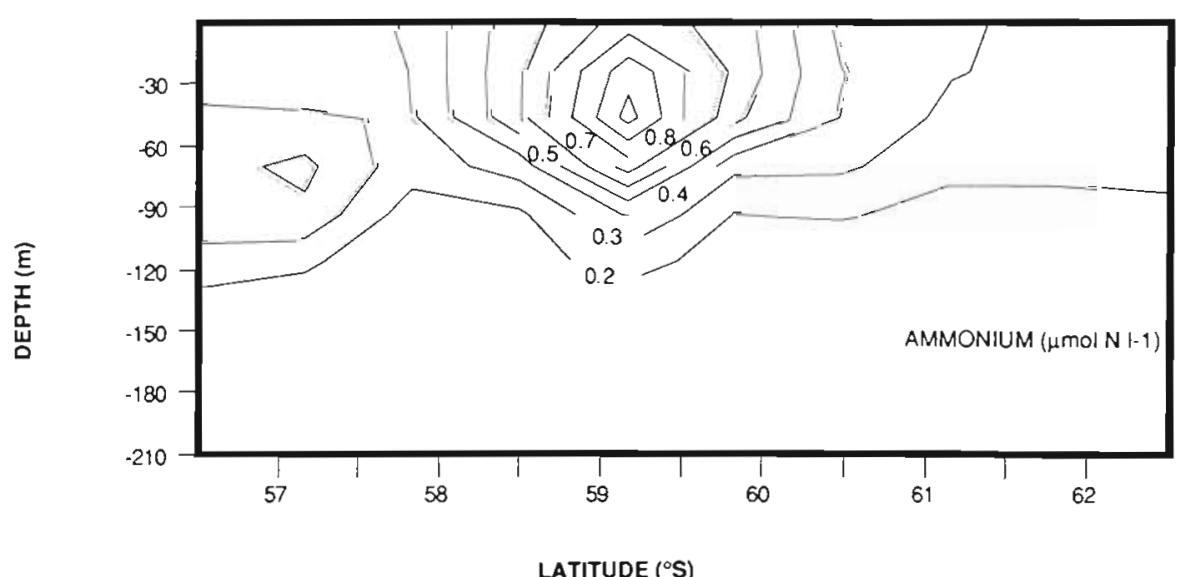


ties correspond to a salinity of 33.6 psu in the surface layer. The southernmost part of this transect was again very low in ammonium and the nitrate concentrations approached winter water conditions. In the compartment north of the Scotia Front, surface nitrate concentrations amounted to $24.6 \mu \mathrm{mol} \mathrm{N} \mathrm{N}^{-1}$ and the highest ammonium concentrations were ca $0.9 \mu \mathrm{mol} \mathrm{N} \mathrm{^{-1 }}$.

An analogous distinction between northern, central and southern parts of the study area for the eastern transect $\mathrm{E}$ confirms this general picture, although the different characteristics were generally less pronounced (Fig. 4). North of the Scotia Front nitrate concentrations at the surface were about $27.5 \mu \mathrm{mol} \mathrm{N} \mathrm{l^{-1 }}$ and maximal ammonium concentrations were $0.6 \mu \mathrm{mol}$ $\mathrm{N}^{-1}$. Along this transect the nitrate concentrations decreased to 22.1 umol $\mathrm{N}^{-1}$ at $59^{\circ} \mathrm{S}$ and the corresponding ammonium maximum was $2.0 \mu \mathrm{mol} \mathrm{N} \mathrm{l}^{-1}$. Finally, at the southernmost stations surface nitrate amounted to $28 \mu \mathrm{mol} \mathrm{N}^{-1}$ and ammonium reached concentrations of $0.4 \mu \mathrm{mol} \mathrm{N}{ }^{-1}$.

\section{Nitrate depletion in the surface layer}

Summer stratification in the Antarctic Ocean is characterized by seasonally warmed and less saline surface water overlying the remnant of the winter mixed layer marked by a temperature minimum. The latter layer is called the winter water. Differences between the winter nitrate concentrations (temperature minimum layer) and the concentrations in the surface layer are defined as depletions (Le Corre \& Minas 1983, Jennings et al. 1984). The term 'depletion' signifies in this context the amount of nitrate removed from the water column during the ongoing growth season and leads to an estimate of seasonal phytoplankton productivity. It is used in the same sense as by Jennings et al. (1984) and must be distinguished from the notion of very low concentrations, limiting phytoplankton growth. However, for temperature minimum layers within the euphotic zone this approach can underestimate the nitrate depletion. Therefore, we based our calculations on an average winter nitrate concentration. For the Weddell Sea stations (south of the Scotia Front) only nitrate data for the temperature minimum layer or for the layer beneath the euphotic zone at stations as far south as $61^{\circ} 30^{\prime}$ and $62^{\circ} \mathrm{S}$ are considered. For 5 of them the mean value amounts to $31.5 \pm 0.2 \mu \mathrm{mol} \mathrm{N} \mathrm{l}^{-1}$. Two of these southernmost stations show nitrate concentrations of $32 \mu \mathrm{mol} \mathrm{N} 1^{-1}$ and more in the temperature minimum layer When compared to Jennings et al. (1984) and to Kamykowski \& Zentara (1989), these values are exceptionally high and are anomalous in the general distribution patterns (Figs. 2, 3 \& 4). For this reason these markedly higher nitrate concentrations in the winter water are only considered for the estimation of the depletion at that station, but not for the calculation of the average winter value. For the Scotia Sea stations (north of the Scotia Front) we used an average winter nitrate concentration of $29.5 \pm 0.3 \mu \mathrm{mol} \mathrm{N}^{-1}$, based on temperature minimum data of the EPOS LEG 2 cruise, which have been confirmed by data from the more recent ANT IX/2 cruise (Goeyens et al. 1991).

In order to estimate algal productivity for every station, nitrate depletions in the water column were calculated and integrated over the depth of the wind-mixed layer (WML depletion) and down to the depth where the in situ nitrate concentration reaches the winter value (total depletion). Depth values for the windmixed layer were obtained from Veth (1991). The data set, shown in Table 1, provides values for the seasonal nitrate assimilation in each particular water column. The highest depletions were measured in the central zone. Exceptionally, they amounted to more than $1000 \mathrm{mmol} \mathrm{N} \mathrm{m}^{-2}$, but usually the values varied between 300 and $600 \mathrm{mmol} \mathrm{N} \mathrm{m}^{-2}$. Farther to the south the depletions decreased drastically and reached values as low as $6 \mathrm{mmol} \mathrm{N} \mathrm{m}^{-2}$.

The contribution by gradient-induced vertical fluxes for each station is estimated by:

$$
\text { Flux }=K \times \frac{\Delta \mathrm{NO}_{3}}{\Delta \text { depth }} .
$$

According to Gordon et al. (1984) the mean coefficient of diffusion $(K)$ is of the order of $0.5 \mathrm{~cm}^{2} \mathrm{~s}^{-1}$. The duration of the productive season was estimated as $50 \mathrm{~d}$ for the first 3 transects (W1, W2 and E), and as $70 \mathrm{~d}$ for the remaining two (W3 and $\mathrm{W} 4$ ). The contribution from vertical flux would then be $9 \% \pm 4$ for all stations. Since this is a very maximum value, no corrections for vertical and horizontal diffusive fluxes are introduced.

\section{New and regenerated production}

We also carried out ${ }^{15} \mathrm{~N}$ incubations on nitrate and ammonium uptake at 15 stations, mainly along the $49^{\circ} \mathrm{W}$ transects. The experimental results are shown in Table 2. Uptake rates are given in nmol $\mathrm{N} \mathrm{I}^{-1} \mathrm{~d}^{-1}$; the $\mathrm{f}-$ ratio (new production as a fraction of total production) was calculated as:

$$
\mathrm{f}=\frac{\mathrm{NO}_{3} \text { uptake }}{\mathrm{NO}_{3} \text { uptake }+\mathrm{NH}_{4} \text { uptake }} .
$$

No other forms of recycled nitrogen, such as urea or organic nitrogen, were included. The integrated amount of nitrogen uptake by phytoplankton in the wind-mixed layer was derived from incubation data for one sample taken in the wind-mixed layer. The mean nitrate uptake rate for all stations was $147 \mathrm{nmol} \mathrm{N} \mathrm{l}^{-1}$ 

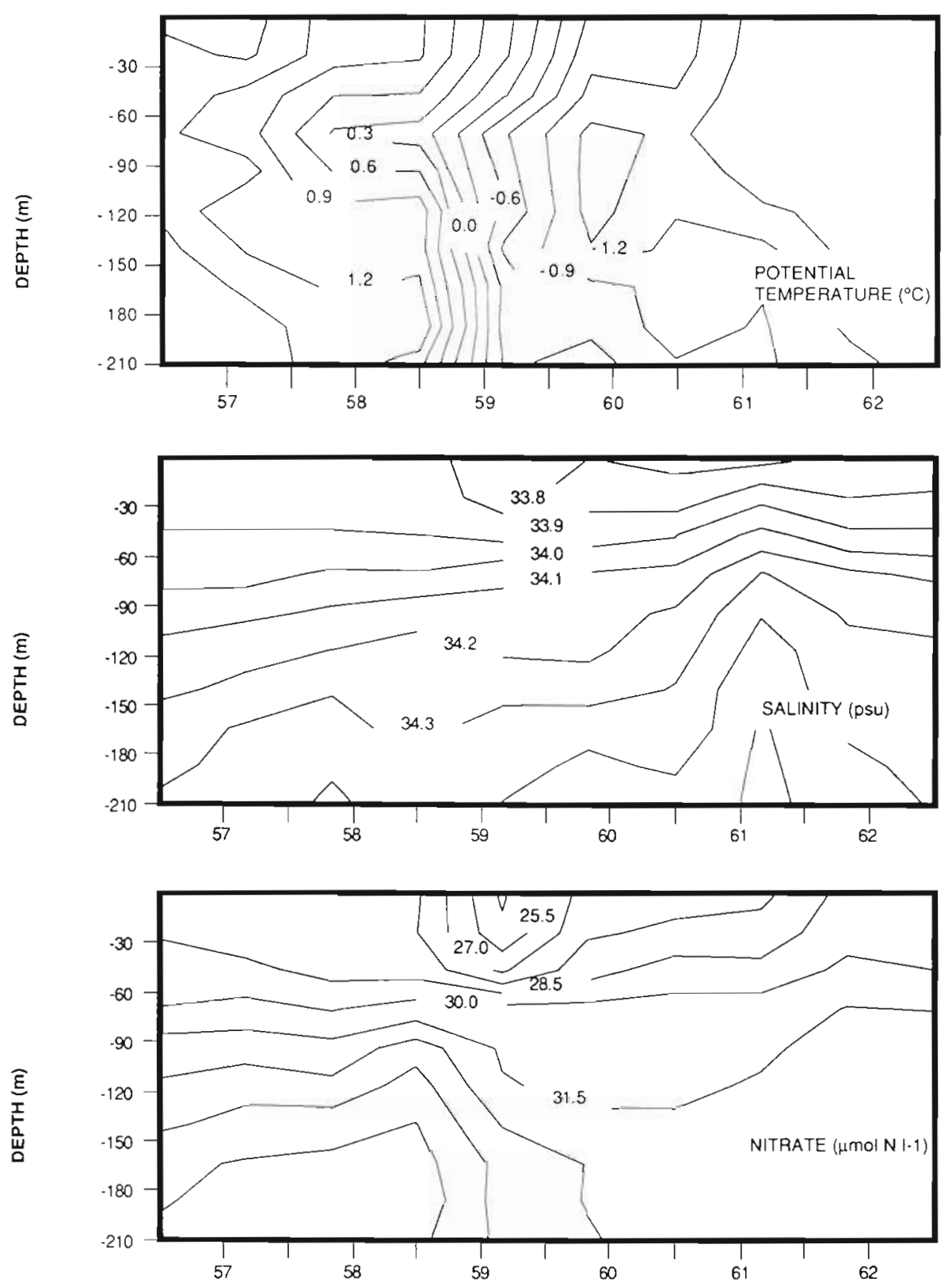

Fig. 4. Vertical distributions of potential temperature $\left({ }^{\circ} \mathrm{C}\right)$, salinity (psu), nitrate ( $\mu \mathrm{mol} \mathrm{N}^{-1}$ ) and ammonium ( $\mu \mathrm{mol} \mathrm{N}^{-1}$ ) for the eastern

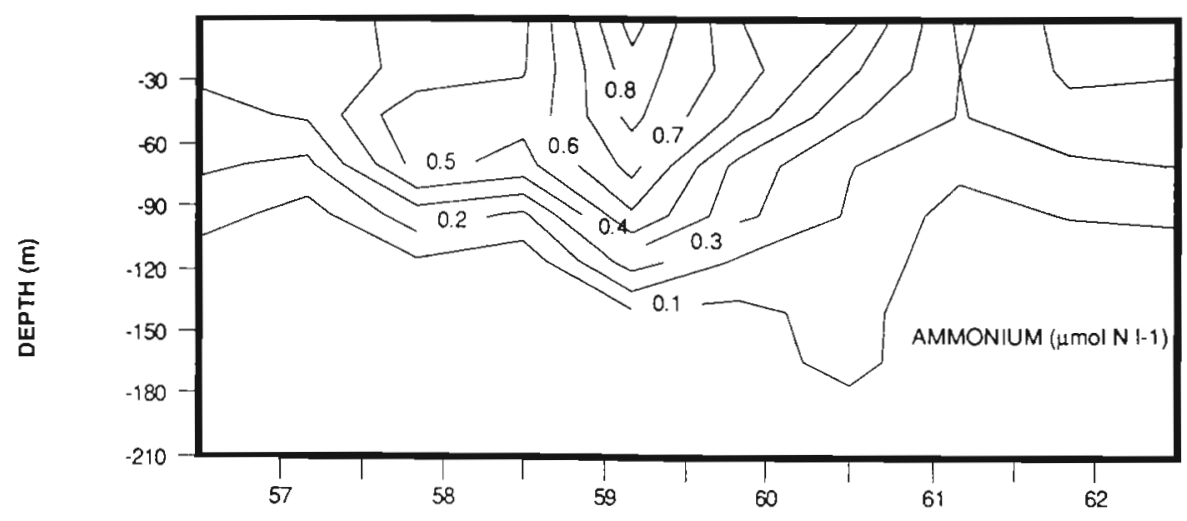
transect $\mathrm{E}$ 
Table 1. Nitrate assimilations during the productive period calculated from nitrate depletions in the wind-mixed layer and over the total depletion depth. (Values at Stns 154 and 155 were insufficient for calculation of nitrate depletions. Values at Stns 158 and 159 are for different vertical profiles)

\begin{tabular}{|c|c|c|c|c|}
\hline \multicolumn{2}{|c|}{ Station } & $\begin{array}{l}\text { Latitude } \\
\left.\qquad{ }^{\circ} \mathrm{S}\right)\end{array}$ & $\begin{array}{l}\text { Total depletion } \\
\left(\mathrm{mmol} \mathrm{N} \mathrm{m}^{-2}\right)\end{array}$ & $\begin{array}{l}\text { WML depletion } \\
\left(\mathrm{mmol} \mathrm{N} \mathrm{m}^{-2}\right)\end{array}$ \\
\hline \multicolumn{5}{|c|}{ Western transects } \\
\hline \multirow[t]{11}{*}{ W1 } & 143 & 57 & 237 & 86 \\
\hline & 144 & 57.5 & 187 & 71 \\
\hline & 145 & 58 & 141 & 89 \\
\hline & 146 & 58.5 & 1024 & 421 \\
\hline & 147 & 59 & 368 & 140 \\
\hline & 148 & 59.5 & 294 & 77 \\
\hline & 149 & 60 & 147 & 85 \\
\hline & 150 & 60.5 & 25 & 10 \\
\hline & 151 & 61 & 27 & 9 \\
\hline & 152 & 61.5 & 44 & 11 \\
\hline & 153 & 62 & 32 & 7 \\
\hline \multirow[t]{7}{*}{ W2 } & 156 & 61 & 6 & 1 \\
\hline & 157 & 59 & 356 & 100 \\
\hline & 158,1 & 59.5 & 1707 & 307 \\
\hline & 158,2 & 59.5 & 134 & 42 \\
\hline & 158,3 & 59.5 & 228 & 90 \\
\hline & 159,1 & 57 & 47 & 44 \\
\hline & 159,2 & 57 & 97 & 71 \\
\hline \multirow[t]{8}{*}{ W3 } & 172 & 59 & 620 & 391 \\
\hline & 173 & 59.5 & 401 & 197 \\
\hline & 174 & 60 & 114 & 53 \\
\hline & 175 & 60.5 & 174 & 33 \\
\hline & 176 & 61 & 91 & 44 \\
\hline & 177 & 61.5 & 86 & 11 \\
\hline & 178 & 61.5 & 46 & 16 \\
\hline & 179 & 62 & 35 & 7 \\
\hline \multirow[t]{11}{*}{ W4 } & 182 & 57 & 135 & 49 \\
\hline & 183 & 57.3 & 222 & 49 \\
\hline & 186 & 58 & 100 & 30 \\
\hline & 187 & 58.5 & 492 & 209 \\
\hline & 188 & 59 & 432 & 295 \\
\hline & 1.89 & 59.5 & 443 & 186 \\
\hline & 190 & 60 & 330 & 136 \\
\hline & 191 & 60.5 & 188 & 76 \\
\hline & 192 & 61 & 112 & 58 \\
\hline & 193 & 61.5 & 130 & 31 \\
\hline & 194 & 61.7 & 96 & 53 \\
\hline \multicolumn{5}{|c|}{ Eastern transect } \\
\hline \multirow[t]{10}{*}{$E$} & 160 & 57 & 82 & 53 \\
\hline & 161 & 57.5 & 123 & 54 \\
\hline & 162 & 58 & 313 & 149 \\
\hline & 163 & 58.5 & 261 & 117 \\
\hline & 164 & 59 & 438 & 306 \\
\hline & 165 & 59.5 & 411 & 140 \\
\hline & 166 & 60 & 291 & 1.42 \\
\hline & 167 & 60.5 & 260 & 137 \\
\hline & 168 & 61 & 220 & 81 \\
\hline & 169 & 61.5 & 112 & 73 \\
\hline
\end{tabular}

$\mathrm{d}^{-1}$, the difference between the highest $\left(482 \mathrm{nmol} \mathrm{N} 1^{-1}\right.$

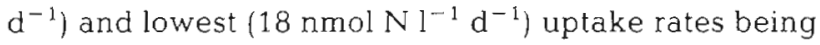
greater than one order of magnitude, however. For ammonium the mean uptake rate amounted to $80 \mathrm{nmol}$ $\mathrm{N}^{-1} \mathrm{~d}^{-1}$, varying between 146 and $29 \mathrm{nmol} \mathrm{N} \mathrm{l}^{-1} \mathrm{~d}^{-1}$.

These data were completed by a series of ${ }^{14} \mathrm{C}$ primary production measurements (Table 3); uptake rates were integrated over the wind-mixed layer (WML PP) as well as over the entire depth of the euphotic zone (total PP). The primary production $\left({ }^{14} \mathrm{C}\right)$ data were translated into nitrogen production by multiplication by the PON:POC ratio for total suspended matter (TSM), measured at the corresponding depth. This method makes it possible to test data abtained from ${ }^{15} \mathrm{~N}$ incubations with independently obtained primary production data, and the correlation for wind-mixed layer integrated values appears to be very good (Fig. 5). The linear regression equation is:

$$
y=-0.16+1.19 x \quad(\mathrm{R}=0.993)
$$

where $y=$ nitrogen production calculated from ${ }^{14} \mathrm{C}$ primary production data: $X=$ nitrogen production as a result of ${ }^{15} \mathrm{~N}$ incubations.

\section{DISCUSSION}

The area studied during EPOS LEG 2 is well represented by an overview (Fig. 6), based on data of the eastern transect $E$ and of the last western transect $W 4$. The central sector, between 59 and $60^{\circ} \mathrm{S}$, was characterized by decreased surface salinities; the lowest salinities measured here amounted to $33.6 \mathrm{psu}$, which is about $2 \%$ below the winter water value. This decrease was evidently due to ice melt, the maximal ice cover gradient of Transects $E$ and W4 being located at $60^{\circ} 30^{\prime}$ and $61^{\circ} \mathrm{S}$ respectively.

The minimal nitrate concentrations measured in this central zone were, however, largely more than $2 \%$ below the winter concentration. A value of $19 \mu \mathrm{mol} \mathrm{N} l^{-1}$, as measured during Transect $W 1$, differs from the winter concentration by ca $40 \%$ and must be explained by assimilation by phytoplankton rather than by dilution with melting ice. The integrated amounts of nitrate removed from the water column between the previous winter and the sampling time, as represented in Fig. 6, refer specifically to new production, as defined by Dugdale \& Goering (1967), during the productive period. The maximal total nitrate depletion of $492 \mathrm{mmol} \mathrm{N} \mathrm{m}^{-2}$ measured along the western transect was very similar to the maximum of $438 \mathrm{mmol} \mathrm{N} \mathrm{m}^{-2}$ measured at $47^{\circ} \mathrm{W}$. These results clearly show that an intensive biological activity zone extended from $58^{\circ} 30^{\prime}$ to $59^{\circ} 30^{\prime}$ S at the time of sampling. Further to the south there was a decrease in nitrate depletion towards $130 \mathrm{mmol} \mathrm{Nm}^{-2}$ and $112 \mathrm{mmol}$ $\mathrm{N} \mathrm{m}^{-2}$ at $61^{\circ} 30^{\prime} \mathrm{S}$ and to less than $100 \mathrm{mmol} \mathrm{N} \mathrm{m}^{-2}$ at $62^{\circ} \mathrm{S}$. This was probably due to both a lower primary production and a shorter production period. 
Table 2. Uptake rates for nitrate and ammonium in the wind-mixed layer (WML)

\begin{tabular}{|c|c|c|c|c|c|c|c|c|}
\hline Station & $\begin{array}{l}\text { Latitude } \\
\left.\qquad{ }^{\circ} \mathrm{S}\right)\end{array}$ & $\begin{array}{l}\text { WML } \\
(\mathrm{m})\end{array}$ & $\begin{array}{l}\mathrm{NO}_{3} \text { uptake rate } \\
\text { (nmol } \mathrm{N}^{-1} \mathrm{~d}^{-1} \text { ) }\end{array}$ & $\begin{array}{l}\mathrm{NH}_{4} \text { uptake rate } \\
\left.\text { (nmol } \mathrm{N}^{-1} \mathrm{~d}^{-1}\right)\end{array}$ & $\begin{array}{l}\text { Total N uptake } \\
\left.\text { (nmol } \mathrm{N} \mathrm{l}^{-1} \mathrm{~d}^{-1}\right)\end{array}$ & $\begin{array}{c}\text { Integrated } \\
\mathrm{NO}_{3} \text { uptake } \\
(\mathrm{mmol} \mathrm{N} \\
\left.\mathrm{m}^{-2} \mathrm{~d}^{-1}\right)\end{array}$ & $\begin{array}{c}\text { Integrated } \\
\mathrm{NH}_{4} \text { uptake } \\
(\mathrm{mmol} \mathrm{N} \\
\left.\mathrm{m}^{-2} \mathrm{~d}^{-1}\right)\end{array}$ & f-ratio \\
\hline 143 & 57 & 32 & 38 & 37 & 75 & 1.22 & 1.18 & 0.51 \\
\hline 147 & 59 & 16 & 361 & 110 & 471 & 5.78 & 1.76 & 0.77 \\
\hline 151 & 61 & 13 & 64 & 38 & 102 & 0.83 & 0.49 & 0.63 \\
\hline 156 & 61 & 15 & 73 & 47 & 120 & 1.10 & 0.71 & 0.61 \\
\hline 157,1 & 59 & 11 & 18 & 43 & 61 & 0.20 & 0.47 & 0.30 \\
\hline 157,2 & 59 & 18 & 22 & 51 & 73 & 0.40 & 0.92 & 0.30 \\
\hline 158,1 & 59.5 & 11 & 252 & 146 & 398 & 2.77 & 1.61 & 0.63 \\
\hline 158,2 & 59.5 & 11 & 107 & 43 & 150 & 1.18 & 0.47 & 0.71 \\
\hline 158,3 & 59.5 & 14 & 482 & 102 & 584 & 6.75 & 1.43 & 0.83 \\
\hline 159 & 57 & 14 & 27 & 33 & 60 & 0.36 & 0.45 & 0.45 \\
\hline 160 & 57 & 22 & 24 & 29 & 53 & 0.53 & 0.63 & 0.45 \\
\hline 164 & 59 & 33 & 76 & 133 & 209 & 2.51 & 4.39 & 0.36 \\
\hline 172. & 59 & 36 & 60 & 135 & 195 & 2.16 & 4.86 & 0.31 \\
\hline 173 & 59.5 & 18 & 247 & 132 & 379 & 4.45 & 2.38 & 0.65 \\
\hline 174 & 60 & 14 & 318 & 101 & 419 & 4.45 & 1.41 & 0.78 \\
\hline 175 & 60.5 & 8 & 198 & 134 & 332 & 1.58 & 1.07 & 0.60 \\
\hline 176 & 61 & 16 & 211 & 76 & 287 & 3.38 & 1.22 & 0.74 \\
\hline 177 & 61.5 & 5 & 61 & 47 & 108 & 0.31 & 0.24 & 0.56 \\
\hline
\end{tabular}

Table 3. Integrated carbon uptake rates for the total euphotic zone and for the wind-mixed layer (WML), and corresponding intergrated nitrogen production for the wind-mixed layer. PP: primary production; PON: particulate organic nitrogen; POC: particulate organic carbon; TSM: total suspended matter

\begin{tabular}{|c|c|c|c|c|c|c|}
\hline Station & $\begin{array}{l}\text { Latitude } \\
\quad\left({ }^{\circ} \mathrm{S}\right)\end{array}$ & $\begin{array}{l}\text { WML } \\
(\mathrm{m})\end{array}$ & 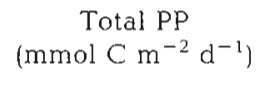 & $\begin{array}{c}\text { WML PP } \\
\left(\mathrm{mmol} \mathrm{C} \mathrm{m} \mathrm{m}^{-2} \mathrm{~d}^{-1}\right)\end{array}$ & $\begin{array}{l}\text { PON : POC } \\
\text { (in TSM) }\end{array}$ & $\begin{array}{c}\text { N-production } \\
\quad(\text { in WML }) \\
\left(\mathrm{mmol} \mathrm{N} \mathrm{m}^{-2} \mathrm{~d}^{-1}\right)\end{array}$ \\
\hline 156 & 61 & 15 & 22.4 & 8.5 & nd & nd \\
\hline 157 & 59 & 19 & 17.3 & 6.4 & 0.15 & 1.00 \\
\hline 158 & 59.5 & 12 & 100.8 & 52.2 & 0.18 & 8.18 \\
\hline 159 & 57 & 26 & 26.0 & 6.9 & 0.14 & 0.81 \\
\hline 169 & 61.5 & 21 & 41.6 & 19.0 & nd & nd \\
\hline 172 & 59 & 36 & 52.5 & 48.8 & 0.18 & 7.02 \\
\hline 174 & 60 & 14 & 80.7 & 37.7 & 0.16 & 5.86 \\
\hline 176 & 61 & 16 & 68.9 & 38.5 & 0.16 & 4.60 \\
\hline 178 & 62 & 12 & 32.6 & 4.5 & nd & nd \\
\hline 188 & 59 & 26 & 41.1 & 37.7 & nd & nd \\
\hline 205 & 59.3 & 32 & 46.3 & 44.6 & nd & nd \\
\hline
\end{tabular}

Additionally, at the same latitudes where nitrate depletions were highest, considerable subsurface ammonium concentrations were measured. Between $59^{\circ}$ and $59^{\circ} 30^{\prime} \mathrm{S}$ the integrated ammonium stocks in the water column increased to values of $200 \mathrm{mmol} \mathrm{N}$ $\mathrm{m}^{-2}$. The upper layer ammonium concentrations were controlled by physical processes (advection and diffusion) as well as by biological processes. Ammonium is assimilated as a nitrogen source, but is also an important reaction product in the remineralization process and is the substrate for bacterial nitrification in deeper waters. In the euphotic zone nitrification rates have consistently been found to be negligible (Olson 1981 , Ward et al. 1982, Enoksson 1986). Enhanced ammonium concentrations clearly indicate the presence of heterotrophic activity in the water. Moreover, the inorganic nitrogen forms characterize a zone of high biological activity, south of the Scotia Front and about $1^{\circ}$ north of the steepest ice cover gradient. A minor delay between ice retreat and appearance of biological activity can explain the more southward extension of the lower salinity zone in comparison with the nitrate depletion zone. These properties fit well with the accepted general scenario: ice melt and water column 


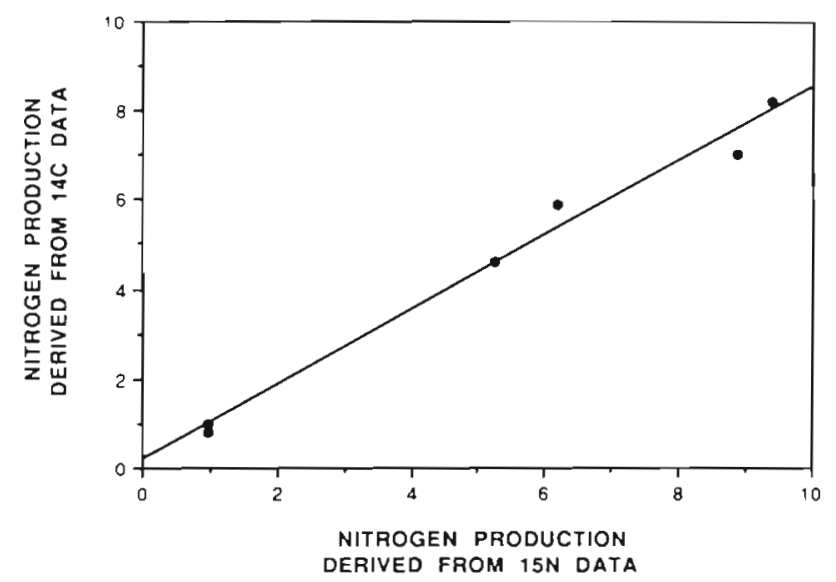

Fig. 5. Nitrogen production ( $\mathrm{mmol} \mathrm{N} \mathrm{m} \mathrm{N}^{-2} \mathrm{~d}^{-1}$ ) as derived from ${ }^{14} \mathrm{C}$ data versus nitrogen production as derived from ${ }^{15} \mathrm{~N}$ data

stabilization inducing phytoplankton blooms and consecutive heterotrophic activity,

High nitrate depletion and nitrate uptake do not signify the absence of ammonium assimilation. Both nitrogen sources, nitrate as well as ammonium, are important in phytoplankton nutrition and are taken up simultaneously. High ammonium levels often inhibit the nitrate uptake, but the effect is variable and usually does not lead to complete inhibition (Dortch 1990). In the central part of the study area high nitrate depletions as well as large ammonium stocks were found. Whether the system is based on new or regenerated production is indicated by the f-ratios (Table 2). Data from the nitrogen uptake experiments show that for the southernmost stations the f-ratios were always in favor of nitrate uptake: an average of $0.7 \pm 0.1$ was found for the stations at $60^{\circ} \mathrm{S}$ and higher latitudes. For the first western transect (from 27 to 30 November 1988) new production dominated at every latitude, even at $57^{\circ} \mathrm{S}$. During Transect W4 (27 to 31 December 1988) the northernmost latitude with f-ratios favoring nitrate uptake was $59^{\circ} 30^{\prime} \mathrm{S}$, while the more northward-situated stations exhibited a pronounced increase of the importance of ammonium uptake.

A comparison of the values of nitrate depletions and the measured nitrogen uptake rates at the different stations can be used to describe the ecosystem's phytoplankton production. The mathematical approaches and the interpretation of the data we used for this are based on values for the wind-mixed layer. Data in Table 1 illustrate that on average the total nitrate depletion is slightly more than twice the wind-mixed layer depletion. A comparison of the integrated primary production values in the euphotic zone and in the wind-mixed layer (Table 3 ) indicated that on average $50 \% \pm 25 \%(n=10)$ took place in the wind-mixed layer. Although the variability in these calculations is rather large, this average fits well with the ratio of wind-mixed layer integrated nitrate depletion to total depletion for the same stations, which amounts to $47 \%$ \pm 21 . This comparable result for 2 sets of data corresponding to largely differing time scales justifies their parallel use in describing the ecosystem. There is also good agreement between nitrogen production values derived from ${ }^{14} \mathrm{C}$ experiments and from ${ }^{15} \mathrm{~N}$ experiments (Fig. 5), which underpins this statement. The molar uptake ratios of carbon to nitrogen amount to between 4.8 and 6.3 , which is very close to the ratio of 6.6 found by Redfield et al. (1963) for the composition of marine phytoplankton. These ratios also agree with the
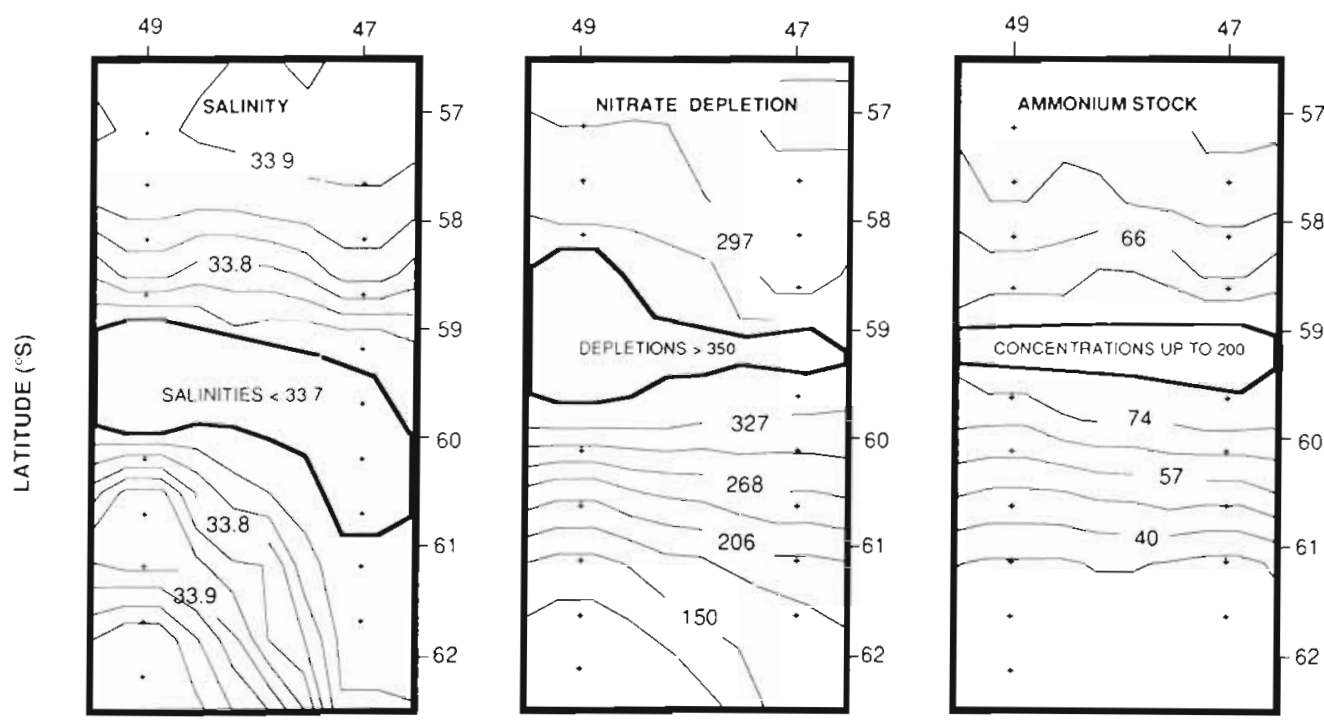

LONGITUDE ( $\left.{ }^{\circ} W\right)$

Fig. 6. Distributions of surface salinity (psu), nitrate depletion ( $m$ mol $\mathrm{N} \mathrm{m}^{-2}$ ) and ammonium stock ( $m$ mol $\mathrm{N} \mathrm{m}^{-2}$ ) in the study area 
Table 4. Estimate of bloom season duration from nitrate anomalies and corresponding nitrate uptake rates

\begin{tabular}{|c|c|c|c|c|c|c|}
\hline Station & $\begin{array}{l}\text { Latitude } \\
\qquad\left({ }^{\circ} \mathrm{S}\right)\end{array}$ & Sampling date & $\begin{array}{c}\text { Ice cover } \\
(\%)\end{array}$ & $\begin{array}{c}\text { Integrated } \\
\mathrm{NO}_{3} \text { uptake } \\
\left(\mathrm{mmol} \mathrm{N} \mathrm{m} \mathrm{m}^{-2} \mathrm{~d}^{-1}\right)\end{array}$ & $\begin{array}{c}\text { Integrated } \\
\mathrm{NO}_{3} \text { depletion } \\
\left(\mathrm{mmol} \mathrm{N} \mathrm{m}^{-2}\right)\end{array}$ & $\begin{array}{l}\text { Duration } \\
\text { (d) }\end{array}$ \\
\hline 143 & 57 & 26 Nov 88 & 0 & 1.22 & 86 & 70 \\
\hline 147 & 59 & 28 Nov 88 & 0 & 5.78 & 140 & 24 \\
\hline 151 & 61 & 29 Nov 88 & 75 & 0.83 & 9 & 11 \\
\hline 156 & 61 & 03 Dec 88 & 50 & 1.10 & 1 & 1 \\
\hline 157,1 & 59 & 06 Dec 88 & 1 & 0.20 & 100 & 500 \\
\hline 157,2 & 59 & 07 Dec 88 & 1 & 0.40 & 100 & 250 \\
\hline 158,1 & 59.5 & $08 \mathrm{Dec} 88$ & 5 & 2.77 & 307 & 111 \\
\hline 158,2 & 59.5 & 08 Dec 88 & 5 & 1.18 & 42 & 36 \\
\hline 158,3 & 59.5 & 09 Dec 88 & 5 & 6.75 & 90 & 13 \\
\hline 159 & 57 & 10 Dec 88 & 0 & 0.36 & 44 & 122 \\
\hline 160 & 57 & 13 Dec 88 & 0 & 0.53 & 53 & 100 \\
\hline 164 & 59 & $14 \operatorname{Dec} 88$ & 0 & 2.51 & 306 & 122 \\
\hline 172 & 59 & 20 Dec 88 & 0 & 2.16 & 391 & 181 \\
\hline 173 & 59.5 & 20 Dec 88 & 0 & 4.45 & 197 & 44 \\
\hline 174 & 60 & 21 Dec 88 & 0 & 4.45 & 35 & 8 \\
\hline 175 & 60.5 & $21 \operatorname{Dec} 88$ & 0 & 1.58 & 33 & 21 \\
\hline 176 & 61 & $22 \operatorname{Dec} 88$ & 50 & 3.38 & 33 & 10 \\
\hline 177 & 61.5 & $22 \operatorname{Dec} 88$ & 80 & 0.31 & 11 & 35 \\
\hline
\end{tabular}

measured molar ratios of the particulate matter in the surface water ( 5.5 to 7.2 ). It should be mentioned here that the $\mathrm{C}: \mathrm{N}$ ratios for TSM slightly exceed those for uptake fluxes; this must be explained by the presence of some detritus. The relative degradation rate for nitrogen is generally supposed to be higher than for carbon, leading to an increase in the $C: N$ ratio during remineralization.

Nelson et al. (1987) state that quantitative estimates of the effects of ice edge blooms on nutrient depletion, primary productivity and sediment accumulation all depend upon assumptions of the bloom's duration. The integrated nitrate depletion constitutes the minimal amount removed from the water by biological processes, mainly assimilation by phytoplankton. Since a correct estimation of the time of start of the bloom is very difficult, a translation of the nitrate depletion into an average uptake rate for nitrate is very inexact. The reverse procedure, using nitrate depletion data and uptake rates for identical water masses, can give an estimate of how long the nitrate uptake lasted, assuming that the uptake remained constant during the complete process. Over 4 consecutive transects along $49^{\circ} \mathrm{W}$ the greatest ice cover gradient moved southward at a speed of ca $1^{\circ}$ latitude per month (Lancelot et al. 1991). It can thus be deduced that the study area was ice-free 1 to 2 mo before sampling. In other words, the durations of nitrate uptake, calculated as the depletion divided by the uptake rate, can never exceed $60 \mathrm{~d}$, if they are to be considered realistic. Otherwise the assumption of constant uptake has to be rejected.

These calculations are summarized in Table 4 for integrated nitrate depletions and integrated nitrate uptake rates. The calculations are made for the windmixed layer only, since no nitrogen uptake data at greater depths are available. The estimated durations fall into 2 well-separated groups, one with acceptable values within the maximal time of ice retreat at that spot, the second with completely aberrant values. The first group, with calculated durations of less than 2 mo, shows an average of $20 \mathrm{~d}$, varying from 6 to 34 , which is very plausible compared to the time necessary for ice melting. The other group shows a number of calculated durations that amount to about 10 times as much, $182 \mathrm{~d}$ varying from 70 to 500; this does not at all agree with a seasonal phytoplankton development with a constant rate.

There is a remarkable agreement between realistic estimates of nitrate uptake duration and the f-ratios in favour of nitrate assimilation. On the other hand, at those stations where production is based on reduced nitrogen uptake, the calculated uptake durations give unrealistic estimates, indicating that at these stations the nitrate uptake rates must have been much higher earlier in the season. These relations and also the observed transition from new to regenerated production at the northernmost stations show how a prevailing new production shifts into a prevailing regenerated one during December in this area. When the system transforms into a more regeneration-based one, with lower f-ratios, the nitrate uptake rate drops to levels much below the earlier ones. Several authors have described the Antarctic system as preferentially based on regenerated production (Olson 1980, Glibert et al. 1982, Rönner et al. 1983, Holm-Hansen 1985, Probyn \& Painting 1985). This study suggests that, during spring, the 
ecosystem evolves from a first phase where new production predominates into a second one dominated by regenerated production.

Rather than describing the ecosystem by zonal differentiation, the distinction between several zones, such as open ocean and marginal ice zone, must be understood as a function of the evolution of the ecosystem's development. New production at the beginning of the growth season shifts towards regenerated production after a very short period. When considering the definitions of new and regenerated production (Dugdale \& Goering 1967) as well as their relation to export production (Eppley \& Peterson 1979, Berger et al. 1989, Eppley 1989), the destiny of particulate matter becomes increasingly important. Fischer et al. (1988) clearly described the annual downward flux in the northern Weddell Sea as the smallest ever measured in the world ocean. This particle flux is characterized by an abrupt increase after complete opening of the sea ice and a sudden termination while the ocean is still open. Other flux measurements carried out at high latitudes (Wilson et al. 1986, Wefer 1989) show that the downward flux is restricted to surprisingly short periods in austral summer, which is in good agreement with the shortness of the new production time-span of the growth period. As to the composition of the sedimenting material, several authors agree that biogenic material comprises its major part (Tréguer et al. 1990), with diatom valves being generally more than $95 \%$ of the siliceous biogenic matter in the Weddell Sea (Fisher et al. 1988), On the other hand, Dehairs et al. (1991) and Jacques (1991) have shown that new production in this area is clearly related to a dominant presence of diatoms in the phytoplankton community. Therefore, it can be concluded that in this ecosystem primary productivity at the beginning of the growth season is mainly based on assimilation of oxidized nitrogenous nutrients by a phytoplankton population consisting largely of diatoms. Over about $3 \mathrm{wk}$, the composition of the phytoplankton community changes towards smaller organisms, with much less biogenic silicon, meeting more than two-thirds of their nitrogen needs by taking up reduced forms. This development is also reflected by export of particulate material to greater depths.

The Antarctic pelagic community is obviously distinct from the oligotrophic communities of warm, nutrient-depleted waters. In the North Atlantic Ocean for instance a switch from new to regenerated nitrogen sources occurs after the spring bloom is terminated by nitrate exhaustion (Smetacek 1984). In the Southern Ocean nitrate is almost never depleted to limiting concentrations. In this study the lowest nitrate concentration was $19 \mu \mathrm{mol} \mathrm{N} l^{-1}$ and the lowest measured fratios considerably exceed those given by Eppley
(1989). The seasonal shift to ammonium uptake is mainly driven by phytoplankton preference after a markedly enhanced availability of ammonium in the water column (Goeyens et al. unpubl.) due to heterotrophic activity.

Acknowledgements. Data presented here were collected during the European 'Polarstern' Study (EPOS), sponsored by the European Science Foundation and the Alfred Wegener Institute for Polar and Marine Research. Financial support from the Belgian Science Policy Office (Scientific Research Programmes on Antarctica, ANTAR 08), from C. F. Lundströms Foundation and the Swedish Natural Science Research Council, and from the French Ministry for Education and CNRS, are very gratefully acknowledged. We take the opportunity to thank the captain and the crew members of RV 'Polarstern' for the magnificent treatment on board and for their tireless, able assistance during work. Anna-Kerstin Thell and Aude Leynaert are also thanked for skillful technical assistance.

\section{LITERATURE CITED}

Berger, W. H., Smetacek, V. S., Wefer, G. (1989). Ocean productivity and paleoproductivity - an overview. In: Berger, W. H., Smetacek, V.S., Wefer, G. (eds.) Production of the ocean: present and past. John Wiley, New York, p. 1-48

Biggs, D. C. (1982). Zooplankton excretion and $\mathrm{NH}_{4}$ cycling in near-surface waters of the Southern Ocean. I. Ross Sea, austral summer 1977-1978. Polar Biol. 1: 55-67

Bröckel, K. von, (1981). The importance of nanoplankton within the pelagic antarctic ecosystem. Kieler Meeresforsch. 5: 61-67

Bröckel, K. von, (1985). Primary production data for the southwestern Weddell Sea. Polar Biol. 4: 75-80

Cederlöf, U., Ober, S., Schmidt, R., Svansson, A., Veth, C. (1989). Hydrography. In: Hempel, I., Schalk, P. H., Smetacek, V (eds.) Reports on polar research. Alfred Wegener Institute for Polar Research, Bremerhaven, p. 14-19

Dehairs, F., Stroobants, N., Goeyens, L. (1991). Suspended barite as a tracer of biological activity in the Southern Ocean. Mar. Chem. (in press)

Dortch, Q. (1990). The interaction between ammonium and nitrate uptake in phytoplankton. Mar. Ecol. Prog. Ser 61. 183-201

Dugdale, R. C. Goering, J. J. (1967). Uptake of new and regenerated forms of nitrogen in primary productivity. Limnol. Oceanogr. 12: 196-206

Enoksson, V (1986). Nitrification rates in the Baltic Sea comparison of three isotope techniques. Appl. environ Microbiol. 51: 244-250

EPOS LEG 2 (1989). EPOS LEG 2 data report hydrography, Part 1 Netherlands Institute for Sea Research, Texel

Eppley, R. W. (1989). New production: history, methods, problems. In: Berger, W. H., Smetacek, V S., Wefer, G. (eds.) Production of the ocean: present and past. John Wiley, New York, p. 85-97

Eppley, R. W. Peterson, B. J. (1979). Particulate organic matter flux and planktonic new production in the deep ocean. Nature, Lond. 282: 677-680

Fischer, G., Futterer, D., Gersonde, R., Honjo, S., Ostermann, D., Wefer, G. (1988). Seasonal variability of particle flux in the Weddell Sea and its relation to ice cover. Nature, Lond. 335: $426-428$

Glibert, P. M., Biggs, D. C., McCarthy, J. J. (1982\}. Utilization 
of ammonium and nitrate during austral summer in the Scotia Sea. Deep Sea Res. 29: 837-850

Goeyens, L., Farbach, E., Behmann, T., Hinrichsen, H., Krest. J., Ross, A., Wisotski, A. (1991). Summer Weddell Gyre study. Data Report No. 1, Alfred Wegener Institute for Polar Research, Bremerhaven

Gordon, A. L., Chen, C. T. A., Metcalf, W. G. (1984). Winter mixed layer entrainment of Weddell deep water. J. geophys. Res. 89: 637-640

Gordon, A. L., Molinelli, E. J. (1982). Thermohaline and chemical distributions and the atlas data set. In: Gordon, A. L. (ed.) Southern Ocean atlas. Gulab Primlani, New Delhi, p. 1-14

Holm-Hansen, O. (1985). Nutrient cycles in antarctic marine ecosystems. In: Siegfried, W. R., Condy, P. R., Laws, R. M. (eds.) Antarctic nutrient cycles and food webs. Springer Verlag, Berlin, p. 6-10

Jacques, G. (1991). Is the concept new production - regenerated production valid for the Southern Ocean? Mar. Chem. (in press)

Jennings, J. C., Gordon, L. I., Nelson, D. M. (1984). Nutrient depletion indicates high primary productivity in the Weddell Sea. Nature, Lond. 309: 51-54

Jones, E. P., Nelson, D. M., Tréguer, P. (1990). Chemical oceanography of the Arctic and Antarctic Ocean. In: Smith, W. O. Jr (ed.) Polar oceanography. Academic Press, San Diego, p. 407-476

Kamykowski, D., Zentara, S. J. (1985). Nitrate and silicic acid in the world ocean: patterns and processes. Mar. Ecol. Prog. Ser. 26: 47-59

Kamykowski, D., Zentara, S. J. (1989). Circumpolar plant nutrient covariation in the Southern Ocean: patterns and processes. Mar. Ecol. Prog. Ser. 58: 101-111

Kristiansen, S., Paasche, E. (1982). Preparation of ${ }^{15} \mathrm{~N}$ labelled phytoplankton samples for optical emission spectrometry. Limnol. Oceanogr 27: 373-375

Koike, I., Holm-Hansen, O., Biggs, D. C. (1986). Inorganic nitrogen metabolism by Antarctic phytoplankton with special reference to ammonium cycling. Mar. Ecol. Prog. Ser 30: 105-116

Koroleff, F. (1969). Direct determination of ammonia in natural waters as indophenol blue. Comm. Meet Int. Cons. Explor. Sea, C.M-ICES C: 19-22

Lancelot, C., Billen, G., Veth, C., Becquevort, S., Mathot, S (1991). Modelling phytoplankton and bacterial loop dynamics during sea-ice retreat in the Scotia-Weddell area: tentative budget of carbon cycling at the first trophic levels of the planktonic ecosystem. Mar. Chem. (in press)

Le Corre, P., Minas, H. J. (1983). Distribution et évolution des éléments nutritifs dans le secteur indien de l' Océan Antarctique en fin de période estivale. Oceanol. Acta 6: 365-381

Le Jehan, S., Tréguer, P. (1983). Uptake and regeneration $\Delta \mathrm{Si} /$ $\Delta N / \Delta P$ ratios in the Indian Sector of the Southern Ocean Originality of the biological cycle of silicon. Polar Biol. 2: $127-136$

Le Jehan, S., Tréguer, P. (1985). The distribution of inorganic nitrogen, phosphorus, silicon and dissolved organic matter in surface and deep water of the Southern Ocean. In: Siegfried, W. R., Condy, P. R., Laws, R. M. (eds.). Antarctic nutrient cycles and food webs. Springer Verlag, Berlin, p. $22-29$
Nelson, D. M., Smith, W. O. Jr (1986). Phytoplankton bloom dynamics of the western Ross Sea ice edge - II. Mesoscale cycling of nitrogen and silicon. Deep Sea Res. 33: $1389-1412$

Nelson, D.-M., Smith, W. O. Jr, Gordon, L. I., Huber, B. A. (1987). Spring distributions of density, nutrients, and phytoplankton biomass in the ice edge zone of the WeddellScotia Sea. J. geophys. Res. 92: 7181-7190

Olson, R. J. (1980). Nitrate and ammonium uptake in antarctic waters. Limnol. Oceanogr. 25: 1064-1074

Olson, R. J. (1981). ${ }^{15} \mathrm{~N}$ tracer studies of the primary nitrite maximum. J. mar. Res. 39: 203-226

Probyn, T A., Painting, S. J. (1985). Nitrogen uptake by size fractionated phytoplankton populations in Antarctic surface waters. Limnol. Oceanogr. 30: 1327-1332

Redfield, A. C., Ketchum, B. H., Richards, F. A. (1963). The influence of organisms on the composition of sea water. In: Hill, M. N. (ed.) The sea, Vol. 2. Wiley, New York, p. 26-77

Rönner, U., Sörensson, F., Holm-Hansen, O. (1983). Nitrogen assimilation by phytoplankton in the Scotia Sea. Polar Biol. 2: $137-147$

Sharp, J. H. (1983). Distribution of inorganic and organic nitrogen in the sea. In: Carpenter, E. J., Capone, D. G. (eds.) Nitrogen in the marine environment. Academic Press, New York, p. 1-35

Smetacek, V. (1984). The supply of food to the benthos. In Fasham, M. J. (ed.). Flows of energy and materials in marine ecosystems: theory and practice. Plenum Press New York, p. 517-548

Smetacek, V., Veth, C. (1989). Scientific objectives of EPOS leg 2. In: Hempel, I., Schalk, P. H., Smetacek, V (eds.) Reports on polar research. Alfred Wegener Institute for Polar Research, Bremerhaven, p. 1-2

Smith, W O. Jr, Harrison, W. G. (1991). New production in polar regions: the role of environmental controls. Deep Sea Res. (in press)

Smith, W. O. Jr, Nelson, D. M. (1990). Phytoplankton growth and new production in the Weddell Sea marginal ice zone in the austral spring and autumn. Limnol. Oceanogr. 35: 809-821

Tréguer, P., Le Corre, P. (1975). Manuel d' analyses automatiques des sels nutritifs par AutoAnalyser II Technicon. Université de Bretagne Occidentale, Brest

Tréguer, P., Nelson, D., Guenely, S., Zeyons, C., Morvan, J. Buma, A. (1990). The distribution of biogenic and lithogenic silica and the composition of particulate organic matter in the Scotia Sea and the Drake Passage during autumn 1987. Deep Sea Res. 90: 883-851

Veth, C. (1991). The evolution of the upper water layer in the marginal ice zone, austral spring 1988, Scotia-Weddell Sea. J. mar. Syst. 2: 451-464

Ward, B. B., Olson, R. J., Perry, M. J. (1982). Microbial nitrification rates in the primary nitrite maximum off Southern California. Deep Sea Res. 29: 247-255

Wefer, G. (1989). Particle flux in the ocean: effects of episodic production. In: Berger, W. H., Smetacek, V. S., Wefer, G. (eds.) Production of the ocean: present and past. John Wiley, New York, p. 139-154

Wilson, D. L., Smith, W. O. Jr, Nelson, D. M. (1986). Phytoplankton bloom dynamics of the Western Ross Sea ice edge - I. Primary productivity and species-specific production. Deep Sea Res. 33: 1375-1387

Manuscript first received: March 15, 1991

Revised version accepted: September 3,1991 